\title{
Uses and Gratifications on Augmented Reality Games: An Examination of Pokémon Go
}

\author{
Salvador Bueno ${ }^{1, *}$, M. Dolores Gallego ${ }^{1}$ and Jan Noyes ${ }^{2}$ \\ 1 Department of Management and Marketing, Universidad Pablo de Olavide, 41013 Seville, Spain; \\ mdgalper@upo.es \\ 2 Department of Psychology, University of Bristol, Bristol BS8 1TH, UK; J.Noyes@bristol.ac.uk \\ * Correspondence: sbueavi@upo.es
}

Received: 22 January 2020; Accepted: 26 February 2020; Published: 1 March 2020

\begin{abstract}
Users are attracted by augmented reality games to fulfil their needs. Two objectives are proposed: (1) to research the motivations of those using augmented reality mobile games; (2) to define a structural model based on Uses and Gratifications Theory for the adoption of augmented reality mobile games. The present study examines the case of Pokémon Go. The model is composed of eight constructs: enjoyment, fantasy, escapism, social interaction, social presence, achievement, self-presentation and continuance intention. The SEM model was empirically assessed based on 1183 responses from Pokémon Go users around the world. Results clearly confirmed the positive influence of almost all the proposed constructs on continuance intention for Pokémon Go. First, these findings may be helpful for the online gaming industry in identifying the game functions that retain more gamers and improve the user experience. Second, the online gaming industry might use these results in order to classify those players with behaviours that favour the use of online games.
\end{abstract}

Keywords: augmented reality games; uses and gratifications theory; Pokémon Go

\section{Introduction}

Digital technologies are changing ways of working, studying, communicating and entertaining [1,2], among other things. During the past few years, the continuous growth of the use of mobile devices and media technologies has transformed traditional games [3-5]. In this context, mobile device gaming has opened up new dimensions for entertainment applications [6].

This article is focused on the use of Pokémon Go game, one of the most popular smartphone games of all time [7-10]. It was launched by the company Niantic Lab in July 2016 and immediately became a global phenomenon [11]. According to [12], this game has reached 1 billion downloads and it is available in more than 90 countries [13]. In addition, as stated in [14], based on December 2018 statistics, Pokémon Go dominates the location-based game category in terms of revenue.

Pokémon Go players must capture virtual characters (Figure 1) mapped to real-world locations [15-17]. At a certain point in the game, players have to join one of three teams and battle for the prestige and ownership of gyms [18], which can be found at real locations in the world, with their Pokémon. The objective of Niantic, a software development company specialized in augmented reality mobile games, was to develop a product that would encourage exercise, but not in a heavy-handed way [19]. Currently, Pokémon Go is included in the augmented reality mobile games category $[4,8]$.

Considering that Pokémon Go pioneered more sophisticated software because of the need for location information $[20,21]$, developers and game companies will be building this into future games. Thus, it is necessary for the online game industry to develop an understanding of the players' intentions [22-25]. 


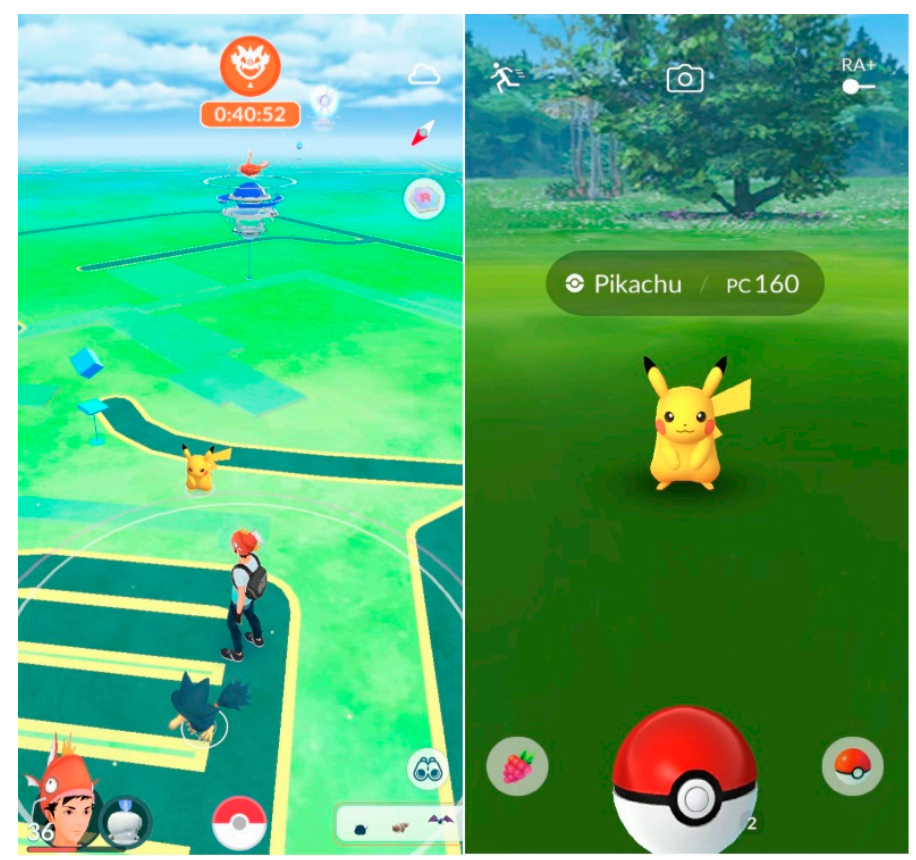

Figure 1. Pokémon Go interfaces.

Two objectives are proposed: (1) to research the motivations of those using augmented reality mobile games; (2) to define a structural model based on the Uses and Gratification Theory [26,27] for the adoption of augmented reality mobile games. Indeed, this theory has been applied widely in Information and Communication Technologies (ICT) research due to its potential for analysing online activities [28,29].

The remainder of this article is as follows: the theoretical background and hypotheses are shown in Section 2. Section 3 then provides the details of the research methodology and preliminary analysis. Thereafter, Section 4 describes the model testing and Section 5 incorporates the discussion. Finally, Section 6 describes conclusions, implications, limitations and future research directions.

\section{Theoretical background}

\subsection{Uses and Gratifications Theory}

The Uses and Gratifications (U\&G) Theory, which originated in [30], aimed to detect the motivational needs of the audience of a radio quiz programme. Thereafter, it has been widely used in research. Recent studies [31-34] legitimate the U\&G approach as one of the most relevant communication theories for explaining the use of media based on the virtual environment.

The U\&G approach originally focused on identifying why people choose one communication medium over another [35-40]. The theory has been used to explore a wide range of topics relating to recent ICT, such as virtual worlds [41-43], online social networking [44], web-based information services [45] and Internet news browsing [46]. However, there are few investigations in the field of augmented reality mobile games that apply the U\&G theory [47].

$U \& G$ principles establish that people usually have a wide range of needs that can be gratified when they consume media $[48,49]$. For that reason, $U \& G$ Theory tries to explain the social and psychological reasons why people are motivated to use media to fulfil their needs [50-52]. In fact, U\&G has the potential to examine personal motivations and persistent use of an augmented reality mobile game, specifically Pokémon Go.

Prior research usually classifies gratifications into three categories [43,53,54]: (1) hedonic, (2) utilitarian, and (3) social. This last one is linked with the attainment of status. Among these three groups, perhaps the hedonic variables have received most attention in studies that try to analyse the 
motivations of those using ICT for leisure and voluntary activities. In this sense, the U\&G approach can be applied to online games as they are a relevant part of the Internet and the media $[53,55]$.

\subsection{Research Model}

The study reported in [53] was identified as one of the few works that apply the U\&G theory in an online game environment. Based on this work, a research model composed of eight constructs related to hedonic, social and utilitarian gratifications was defined (Figure 2). First, hedonic gratification is captured by: (1) enjoyment (ENJ), (2) fantasy (FAN) and (3) escapism (ESC). Second, it is assumed that (4) social interaction (SINT) and (5) social presence (SPRE) describe social gratification. Finally, (6) achievement $(\mathrm{ACH})$ and (7) self-presentation (SELFP) are proposed as capturing utilitarian gratification. All these constructs in turn influence (8) the continuance intention (CI) to use the Pokémon Go game.

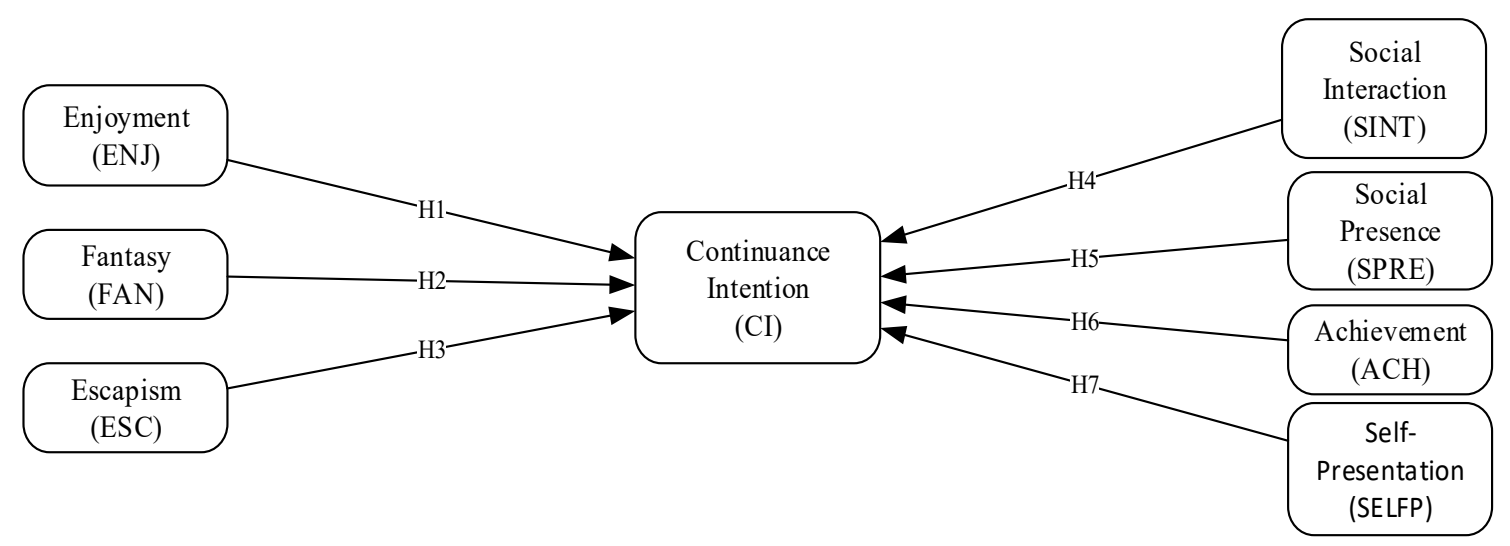

Figure 2. Proposed research model.

Considering this proposal, the present study contributes to an increase the points of view that identify the motivations of the users of Pokémon Go. In fact, the model provides a different perspective when compared with similar studies. For example, [21] analysed the motivations of those continuing to use Pokémon Go, applying the Motives for Online Gaming Questionnaire. In addition, [4] analysed the continued use of Pokémon Go by adopting the Theory of $U \& G$, although the applied model focused on risks and social norms. Finally, [8] analysed the use of Pokémon Go as a tool that drives cognitive performance and emotional intelligence.

In a general way, online games are one type of hedonic ICT [23,53,56-59]. Users can alleviate boredom by playing games linked with mobile phones [60]. In this way, enjoyment is considered as a hedonic gratification [61], inasmuch as it is related to activities which are interesting or enjoyable [62]. Indeed, Prior ICT studies identify enjoyment as the main hedonic motivation [63]. In addition, [64] shows that continuance intention is predicted by enjoyment [64-67]. Based on the above reasoning, enjoyment should exert an influence on continuance intention, and the following hypothesis is posited:

Hypothesis 1 (H1). Enjoyment impacts positively on continuance intention to play the Pokémon Go game.

Moreover, the ICT literature identifies fantasy as one of the dominant dimensions of video game use $[68,69]$ and it has been shown to be a strong predictor in determining user behaviour for online communities and gamers using the U\&G approach [43,47,53,70,71]. According to [72] (p. 4), fantasy "refers to themes that engage users in a creative, imaginative, or even fantasized world of play". Thus, fantasy could be seen in online games as allowing players to do things that they would not normally be able to do in real life $[47,53,73]$, such as building cities or in this case, choosing an avatar with which to catch Pokémon. Hence, in this study, it is expected that fantasy obtained when playing Pokémon Go will increase the continuance intention to play it. Thereby, a hypothesis was established: 
Hypothesis 2 (H2). Fantasy impacts positively on continuance intention to play the Pokémon Go game.

Escapism is another hedonic dimension related to the Internet [40,44,53] and mobile communications [74]. Augmented reality mobile games allow players to escape by removing themselves from the worries of everyday life [75-77]. In addition, many authors identified escapism gratification as one of the most consistent predictors of consumption behaviour [78-83]. Therefore, a hypothesis was suggested:

Hypothesis 3 (H3). Escapism impacts positively on continuance intention to play the Pokémon Go game.

Social interaction is a classical gratification in U\&G studies [84,85]. This dimension includes meeting people with similar interests or keeping up with what is going on [86]. In particular, social interaction helps to sustain social gratification for players and relationships with friends $[63,87]$. When people socialize, they expect to increase their emotional satisfaction.

Therefore, in U\&G studies [53,63,88,89], social interactions have long been considered a meaningful gratification associated with playing online games. Applying this to the present research, we expected that the social interaction gratification from playing Pokémon Go would an effect on continuance intention to keep playing the game. Thereby this hypothesis was defined:

Hypothesis 4 (H4). Social interaction impacts positively on continuance intention to play the Pokémon Go game.

Social media is a practical context for examining social presence in online games. In a general way, users employ social media to share their experiences [90]. In this manner, social presence could show the need of users to interact with their peers using augmented reality mobile games $[42,53,80]$.

In the case of Pókemon Go, players are prompted to be part of Team Instinct (Yellow), Team Mystic (Blue) or Team Valor (Red). Players usually select the same team as their friends in order to reach some common goals. In this sense, social presence could be a dimension associated with continuance intention. Thus, the following hypothesis is proposed:

Hypothesis 5 (H5). Social presence impacts positively on continuance intention to play Pokémon Go.

Achievement has been widely studied in U\&G [43,53]. It was defined by [91] as the desire to gain advancement (power, progress, etc.) and to compete with others, and an interest in analysing the rules and the system. With reference to online games, it is seen as the "desire to gain power, to gather virtual game objects and valuable performance points, to compete with others and to generate a particular image of player-self" [53] (p. 263).

The authors of [92] stated that factors such as optimal experiences, personal interactions or pleasant social interactions determine the continuous use of online games. Moreover, improving status can be considered relevant by users worried about developing their cyber identity or image [42,47]. Applying this to Pokémon Go, players will be keen to gain prestige and a high trainer level. Based on this, it is expected that the relationship between achievement and continuance intention should be positively strong. The following hypothesis is suggested:

Hypothesis 6 (H6). Achievement impacts positively on continuance intention to play the Pokémon Go game.

Finally, self-presentation has been identified as an important aspect of relational development in interpersonal interactions [93]. Through self-presentation, players project an image of self in order to exert an influence on the perception and treatment of other online players [53], besides obtaining rewards and self-fulfilment [94]. Further, the information received from self-presentation is usually used by players to make comparisons with others in order to judge their own abilities [95]. 
Pokémon Go allows players to select their avatars and customise them with clothes and accessories to exhibit the image that players desire. In this manner, Pokémon Go has a huge range of styles and clothing options. Moreover, the use of an avatar maintains users' privacy and gives them expressive freedom to an otherwise anonymous and static online presence $[63,95,96]$. Consequently, the following hypothesis is proposed:

Hypothesis 7 (H7). Self-presentation impacts positively on continuance intention to play the Pokémon Go game.

\section{Research methodology and preliminary analysis}

\subsection{Data collection and Participants}

A web-based survey was designed to collect data in order to test the research model. This included visiting different Facebook groups around the world to invite their members to participate in this research. Players could complete the online questionnaire using the hyperlink provided. A total of 1189 questionnaires were collected, of which six were incomplete. The collection period was between December 2018 and June 2019.

\subsection{Questionnaire Design}

The survey instrument for this study was based on the theoretical background regarding $U \& G$ theory and online games. Concretely, the measurement scales (Appendix A) were extracted from previous studies $[31,53,60]$. A five-point Likert-type scale allowed participants to express their agreement or disagreement with the proposed statements, ranging from not at all/strongly disagree (1) to exactly/strongly agree (5). Additionally, some demographic data were collected in an introductory section (Table 1).

Table 1. Demographic Profile.

\begin{tabular}{ccc}
\hline Dimension & Characteristic & Statistic (\%) \\
\hline \multirow{2}{*}{ Gender } & Male & $581(49.11 \%)$ \\
& Female & $602(50.88 \%)$ \\
\hline \multirow{2}{*}{ Age } & Less than 20 years old & $321(27.2 \%)$ \\
& Between 21 and 25 & $394(33.38 \%)$ \\
& Between 26 and 30 & $226(19.15 \%)$ \\
& Between 31 and 40 & $144(12.20 \%)$ \\
Pokémon Go use frequency & Between 41 and 50 & $78(6.61 \%)$ \\
& More than 50 years old & $20(1.44 \%)$ \\
\hline & Several times a day & $627(53 \%)$ \\
Online Games use frequency & Once a day & $311(26.28 \%)$ \\
& Once a week & $101(8.53 \%)$ \\
& Rarely & $144(12.17 \%)$ \\
\hline & $<5$ hours a week & $363(34.12 \%)$ \\
& Between 5 y 10 hours & $345(32.42 \%)$ \\
& Between 11 y 15 hours & $111(10.43 \%)$ \\
& $>20$ hours a week & $247(23.03 \%)$ \\
\hline
\end{tabular}

\section{Data Analysis and Results}

\subsection{Structural Model Test}

A structural equation model (SEM) was proposed. Lisrel 8.51 and SPPS 25.0 software were used for the data analysis. On the one hand, Cronbach's $\alpha$ coefficient exceeded the minimum acceptable level of 0.70 [97], affirming the reliability of every construct (Table 2). 
On the other hand, the convergent validity of the items was evaluated using two indicators [98]: (1) composite reliability for each construct and (2) average variance extracted (AVE). In this manner, an exploratory factor analysis (EFA) for each construct was developed [99] in order to assess its unidimensionality (Table 2). The results of this analysis show that all constructs widely surpassed the threshold of 0.50 for AVE [100], affirming the convergent validity in all cases.

In addition, the discriminant validity was evaluated. Table 3 shows that the square roots of the AVEs are higher than the absolute values of the off-diagonal values in the corresponding rows and columns of the correlation matrix. These findings indicate that each construct is more strongly correlated with its own indicators than with the other constructs in the model [101]. Finally, the model fit indices have been incorporated into Table 4 along with their recommended values. These indicate that the research model has a good fit considering the maximum thresholds proposed by [99].

Table 2. Measurement scales.

\begin{tabular}{|c|c|c|c|c|c|c|c|c|}
\hline \multicolumn{2}{|c|}{ Construct } & \multirow{2}{*}{$\begin{array}{c}\text { Mean } \\
4.26\end{array}$} & \multirow{2}{*}{$\begin{array}{c}\text { Std. D. } \\
0.950\end{array}$} & \multirow{2}{*}{$\begin{array}{c}\text { Factor Loading } \\
0.942\end{array}$} & \multirow{2}{*}{$\begin{array}{c}\text { Lambda Stand. } \\
0.923\end{array}$} & \multirow{2}{*}{$\begin{array}{l}\text { Composite } \\
\text { Reliability } \\
\end{array}$} & \multirow[t]{2}{*}{ AVE } & \multirow{2}{*}{ Cronbach's $\alpha$} \\
\hline & EN1 & & & & & & & \\
\hline ENJ & EN2 & 4.26 & 0.954 & 0.960 & 0.953 & 0.912 & 0.777 & 0.925 \\
\hline & EN3 & 4.13 & 0.980 & 0.796 & 0.756 & & & \\
\hline \multirow{3}{*}{ FAN } & FA1 & 2.77 & 1.30 & 0.826 & 0.832 & \multirow{3}{*}{0.885} & \multirow{3}{*}{0.720} & \multirow{3}{*}{0.883} \\
\hline & FA2 & 2.18 & 1.32 & 0.868 & 0.854 & & & \\
\hline & FA3 & 2.75 & 1.32 & 0.842 & 0.860 & & & \\
\hline \multirow{4}{*}{ ESC } & ES1 & 3.05 & 1.33 & 0.829 & 0.841 & \multirow{4}{*}{0.918} & \multirow{4}{*}{0.736} & \multirow{4}{*}{0.914} \\
\hline & ES2 & 2.50 & 1.33 & 0.869 & 0.870 & & & \\
\hline & ES3 & 2.70 & 1.32 & 0.898 & 0.897 & & & \\
\hline & ES4 & 2.82 & 1.32 & 0.816 & 0.821 & & & \\
\hline \multirow{4}{*}{ SINT } & SIN1 & 2.27 & 1.36 & 0.866 & 0.865 & \multirow{4}{*}{0.956} & \multirow{4}{*}{0.843} & \multirow{4}{*}{0.955} \\
\hline & SIN2 & 2.59 & 1.38 & 0.931 & 0.931 & & & \\
\hline & SIN3 & 2.42 & 1.36 & 0.952 & 0.955 & & & \\
\hline & SIN4 & 2.36 & 1.32 & 0.919 & 0.92 & & & \\
\hline \multirow{3}{*}{ SPRE } & SOP1 & 2.78 & 1.32 & 0.827 & 0.815 & \multirow{3}{*}{0.877} & \multirow{3}{*}{0.705} & \multirow{3}{*}{0.874} \\
\hline & SOP2 & 2.35 & 1.32 & 0.810 & 0.813 & & & \\
\hline & SOP3 & 2.95 & 1.36 & 0.869 & 0.888 & & & \\
\hline \multirow{4}{*}{$\mathrm{ACH}$} & $\mathrm{ACH} 1$ & 3.47 & 1.34 & 0.815 & 0.809 & \multirow{4}{*}{0.922} & \multirow{4}{*}{0.748} & \multirow{4}{*}{0.919} \\
\hline & $\mathrm{ACH} 2$ & 3.02 & 1.4 & 0.910 & 0.933 & & & \\
\hline & ACH3 & 2.96 & 1.39 & 0.876 & 0.904 & & & \\
\hline & $\mathrm{ACH} 4$ & 3.20 & 1.34 & 0.840 & 0.807 & & & \\
\hline \multirow{3}{*}{ SELFP } & SEP1 & 2.58 & 1.31 & 0.948 & 0,954 & \multirow{3}{*}{0.935} & \multirow{3}{*}{0.827} & \\
\hline & SEP2 & 2.66 & 1.32 & 0.957 & 0,951 & & & 0.928 \\
\hline & SEP3 & 2.73 & 1.36 & 0.803 & 0,817 & & & \\
\hline & CI1 & 3.49 & 1.23 & 0.864 & 0.837 & & & \\
\hline $\mathrm{Cl}$ & $\mathrm{CI} 2$ & 3.96 & 1.13 & 0.864 & 0.893 & 0.856 & 0.749 & 0.853 \\
\hline
\end{tabular}

Table 3. Discriminant validity.

\begin{tabular}{ccccccccc}
\hline & ENJ & FAN & ESC & SINT & SPRE & ACH & SELFP & CI \\
\hline Enjoyment (ENJ) & 0.88 & & & & & & & \\
Fantasy (FAN) & 0.245 & 0.94 & & & & & & \\
Escapism (ESC) & 0.357 & 0.397 & 0.96 & & & & & \\
Social Interaction (SINT) & 0.183 & 0.300 & 0.339 & 0.98 & & & & \\
Social Presence (SPRE) & 0.334 & 0.417 & 0.466 & 0.616 & 0.93 & & & \\
Achievement (ACH) & 0.383 & 0.321 & 0.446 & 0.307 & 0.433 & 0.96 & & \\
Self-Presentation (SELFP) & 0.185 & 0.444 & 0.337 & 0.479 & 0.666 & 0.321 & 0.96 & \\
Continuance Intention (CI) & 0.526 & 0.215 & 0.338 & 0.277 & 0.386 & 0.352 & 0.229 & $0.92^{1}$ \\
\hline
\end{tabular}

${ }^{1}$ Diagonal elements are the square root of the shared variance between the constructs and their measures. 
Table 4. Overall fits of the models

\begin{tabular}{ccc}
\hline Fit Index & Results & Recommended Value \\
\hline X 2/grade of freedom & 0.295 & $\leq 3.00$ \\
Normed Fit Index (NFI) & 0.960 & $\geq 0.90$ \\
Non-normed Fit Index (NNFI) & 0.964 & $\geq 0.90$ \\
Comparative Fit Index (CFI) & 0.970 & $\geq 0.90$ \\
Adjusted Goodness-of-Fit Index (AGFI) & 0.915 & $\geq 0.80$ \\
Root Mean Square Error of & 0.050 & $\leq 0.05$ \\
Approximation (RMSEA) & 0.934 & $\geq 0.90$ \\
Goodness-of-Fit Index (GFI) & 0.970 & $\geq 0.90$ \\
Incremental Fit Index (IFI) & & \\
\hline
\end{tabular}

\subsection{Test of the Structural Model}

SEM was used to test the significance for each hypothesised path $(\beta)$ and the explained variance (R2) for each dependent variable, adopting the maximum likelihood estimation method. As shown in Table 5, five of the seven hypotheses are supported.

Table 5. Results of hypothesis testing.

\begin{tabular}{cccc}
\hline Hypothesis $($ Path) & Path Coefficient & t-Value $\mathbf{2}^{\mathbf{2}}$ & Supported \\
\hline $\mathrm{H} 1: \mathrm{ENJ} \rightarrow \mathrm{CI}$ & 0.484 & $12.065^{* * *}$ & Yes \\
$\mathrm{H} 2: \mathrm{FAN} \rightarrow \mathrm{CI}$ & -0.0145 & -0.442 & No \\
$\mathrm{H} 3: \mathrm{ESC} \rightarrow \mathrm{CI}$ & 0.0647 & $1.975^{* *}$ & Yes \\
$\mathrm{H} 4: \mathrm{SINT} \rightarrow \mathrm{CI}$ & 0.0627 & $1.968^{* *}$ & Yes \\
$\mathrm{H} 5: \mathrm{SPRE} \rightarrow \mathrm{CI}$ & 0.155 & $3.166^{* *}$ & Yes \\
$\mathrm{H} 6: \mathrm{ACH} \rightarrow \mathrm{CI}$ & 0.0814 & $2.515^{* *}$ & Yes \\
$\mathrm{H} 7: \mathrm{SELFP} \rightarrow \mathrm{CI}$ & -0.0284 & -0.848 & No \\
\hline
\end{tabular}

${ }^{2}$ Significant at: ${ }^{*} p<0.05 \mathrm{t}(0.05 ; \infty)=1.9670 ;{ }^{* *} p<0.01 ; \mathrm{t}(0.01 ; \infty)=2.5904 ;{ }^{* * *} p<0.001 ; \mathrm{t}(0.001 ; \infty)=3.3195$.

The results displayed in Table 5 show that the model explained $34.2 \%$ of the variance in intention to continue to playing Pokémon Go. As expected, social interaction $(\beta=0.0627155, p<0.01)$, social presence $(\beta=0.155, p<0.001)$, achievement $(\beta=0.0814, p<0.01)$, enjoyment $(\beta=0.484$; $p<0.001)$ and escapism $(\beta=0.0647, p<0.01)$ have a positive impact in Pokémon Go continuance intention. However, fantasy and self-presentation do not obtain a significant path coefficient, hence these relationships are not supported.

\section{Discussion}

The present work has investigated the connections between continuance intention of playing Pokémon Go and a set of constructs: enjoyment, fantasy, escapism, social interaction, social presence, achievement and self-presentation. The $U \& G$ perspective was adopted.

The findings indicate that $U \& G$ theory comprises an appropriate framework, because (1) it broadly explains the voluntary use of ICT for hedonic purposes and (2), specifically, it has enough potential to examine motivations for the continuous use of augmented reality mobile games, such as Pokémon Go. Based on these U\&G principles, people will consume augmented reality mobile games to gratify a wide set of needs.

According to [50,51], U\&G is a useful framework to identify social and psychological needs, and in this way to answer to key questions in the motivational field. In fact, the U\&G approach considers that continuance intention of ICT use depends largely on cognition-oriented behaviour [30-32]. From a theoretical point of view, this study makes a number of contributions. First, it has improved understanding of the essential dimensions that incentive the use of online games. The results confirm the variables that determine continuance intention of online games. Second, results contribute to the 
existing literature by highlighting the impact of gratifications on online game use. In this respect, the structural model, based on prior literature [49,53,59], received strong support from the dataset.

Overall, the model supports almost all relationships as expected. In this respect, the dataset indicates that the proposed model offers an appropriate fit for the defined connections, as the positive influence of enjoyment, escapism, social interaction, social presence and achievement on the CI of playing Pokémon Go are clearly confirmed. These results share some similarities with the previous literature [53,57-59]. However, contrary to what was expected, the hypotheses relating to fantasy and self-presentation were not supported, and so do not seem to be relevant to Pokémon Go. Overall, however, it can be concluded that users achieve gratification when they use augmented reality mobile games.

Finally, this is one of the first studies to examine the intentions of people using an online game with three basic features: it is (1) free-to-play (players do not need to pay to use it), (2) location-based (the progress of the game depend on the player's location) and (3) an augmented reality game.

\section{Conclusions}

This study has been an attempt to test the intention to use augmented reality mobile games, and more specifically Pokémon Go. Concretely, this research extended the U\&G framework and demonstrated the impact of gratifications on players' intentions to continue using Pokémon Go.

Based on the results, some implications have been identified. First, this article has enlarged knowledge about the use and adoption of online games. In this manner, the present study has provided some empirical evidence for subsequent investigations to assess the continuance intention of use of augmented reality mobile games. In contrast, from a managerial perspective, understanding the perceived gratifications associated with online games applications is useful for the online games industry. Some practical implications can be extracted from the results.

First, the findings may be helpful for the online gaming industry in identifying the game functions which retain more gamers and improve the user experience. The results of the present study lay the foundations for incorporating potential gratifications into the design of online games. Second, the online gaming industry might use these results in order to classify those players with behaviours that favour the use of online games, and thus can anticipate the success for this type of online entertainment.

This research is not without limitations. First, this study has not applied stratified sampling, which makes it possible to recruit equal sizes of age groups, and age groups that mirror the current population. The second limitation is related to the explanatory capacity of the model. In this respect, the percentage of the explained variance for continuance intention could have improved if other variables linked to gratifications and players' behaviour had been considered. Finally, the findings from this study are limited to the case of Pokémon Go. To address this, it would be convenient to develop similar studies that encompass other augmented reality mobile games.

Author Contributions: Conceptualization, S.B. and M.D.G.; methodology, S.B., M.D.G. and J.N.; software, S.B., M.D.G.; validation, M.D.G.; formal analysis, S.B. and M.D.G.; investigation, S.B., M.D.G. and J.N.; resources, S.B., M.D.G. and J.N.; data curation, M.D.G.; writing—original draft preparation, S.B., M.D.G. and J.N.; writing-review and editing, S.B., M.D.G. and J.N.; visualization, M.D.G..; supervision, S.B. All authors have read and agreed to the published version of the manuscript.

Funding: This research received no external funding.

Conflicts of Interest: The authors declare no conflict of interest. 
Appendix A Questionnaire

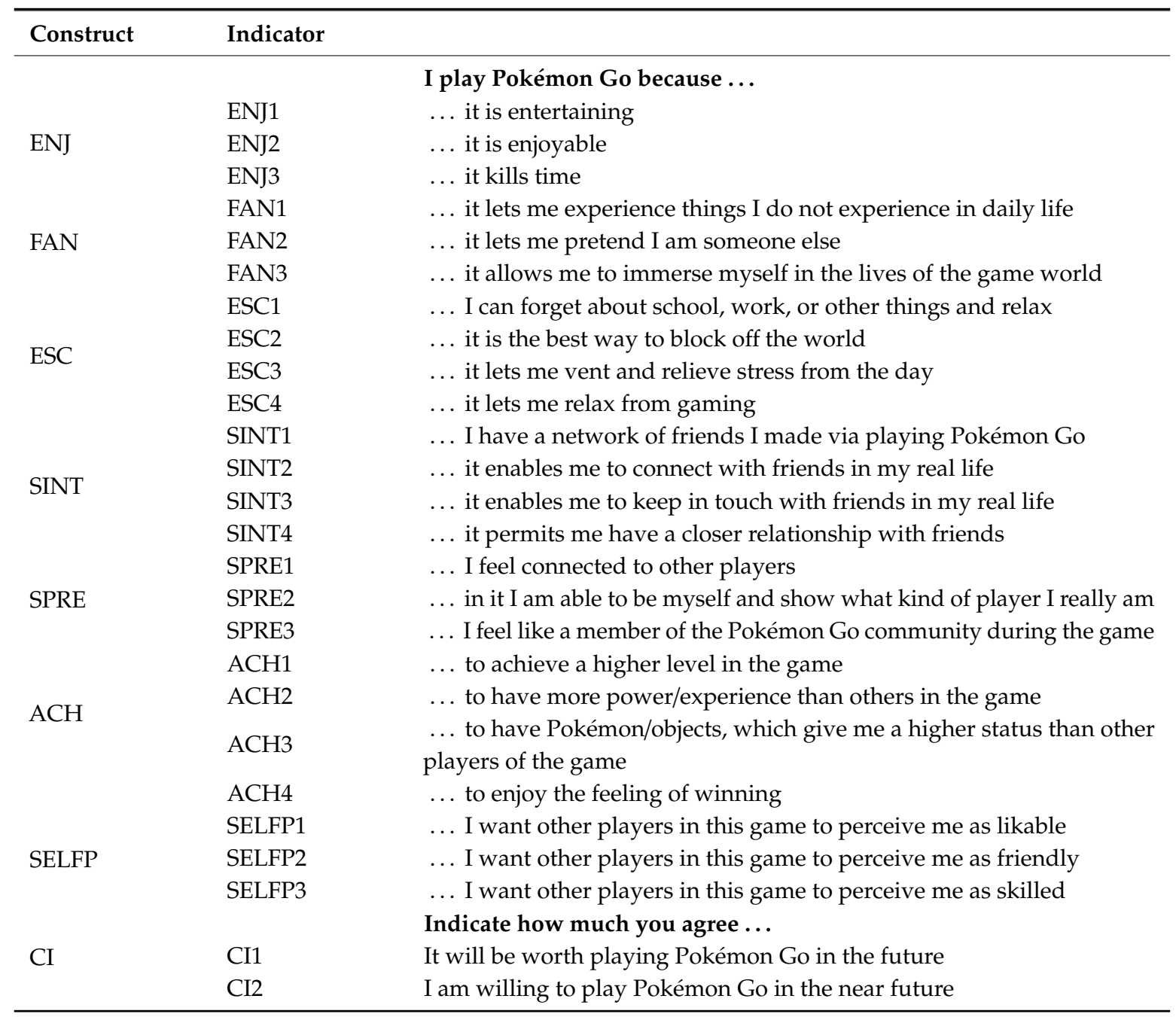

\section{References}

1. Nelson, S.B.; Jarrahi, M.H.; Thomson, L. Mobility of knowledge work and affordances of digital technologies. Int. J. Inform. Manag. 2017, 37, 54-62. [CrossRef]

2. Jabbar, A.; Gasser, R.B.; Lodge, J. Can New Digital Technologies Support Parasitology Teaching and Learning? Trends Parasitol. 2016, 32, 522-530. [CrossRef]

3. Milošević, M.; Živić, N.; Andjelković, I. Early churn prediction with personalized targeting in mobile social games. Expert Syst. Appl. 2017, 326-332. [CrossRef]

4. Rauschnabel, P.A.; Rossmann, A.; tom Dieck, M.C. An adoption framework for mobile augmented reality games: The case of Pokémon Go. Comput. Hum. Behav. 2017, 76, 276-286. [CrossRef]

5. Dhir, A.; Kaur, P.; Rajala, R. Why do young people tag photos on social networking sites? Explaining user intentions. Int. J. Inform. Manag. 2018, 38, 117-127. [CrossRef]

6. Bacchini, D.; De Angelis, G.; Fanara, A. Identity formation in adolescent and emerging adult regular players of massively multiplayer online role-playing games (MMORPG). Comput. Hum. Behav. 2017, 73, 191-199. [CrossRef]

7. Caci, B.; Scrima, F.; Tabacchi, M.E.; Cardaci, M. The reciprocal influences among motivation, personality traits, and game habits for playing Pokémon Go. Int. J. Hum. Comput. Int. 2019, 35, 1303-1311. [CrossRef]

8. Ruiz-Ariza, A.; Casuso, R.A.; Suarez-Manzano, S.; Martínez-López, E.J. Effect of augmented reality game Pokémon GO on cognitive performance and emotional intelligence in adolescent Young. Comput. Educ. 2018, 116, 49-63. [CrossRef] 
9. Kaczmarek, L.D.; Misiak, M.; Behnke, M.; Dziekan, M.; Guzik, P. The Pikachu effect: Social and health gaming motivations lead to greater benefits of Pokémon GO use. Comput. Hum. Behav. 2017, 75, 356-363. [CrossRef]

10. Tabacchi, M.E.; Caci, B.; Cardaci, M.; Perticone, V. Early usage of Pokémon Go and its personality correlates. Comput. Hum. Behav. 2017, 72, 163-169. [CrossRef]

11. Tang, A.K.Y. Key factors in the triumph of Pokémon GO. Bus. Horizons 2017, 60, 725-728. [CrossRef]

12. Pokémon Go YouTube Channel. Available online: https://www.youtube.com/user/PokemonCoJp. (accessed on 16 September 2019).

13. Niantic Labs. Available online: https://www.nianticlabs.com/blog/googlecloud/ (accessed on 17 July 2019).

14. Business of Apps. Available online: https://www.businessofapps.com/data/pokemon-go-statistics/ (accessed on 16 October 2019).

15. Chen, C.S.; Lu, H.P.; Luo, T. A new flow of Location Based Service mobile games: Non-stickiness on Pokémon Go. Comput. Hum. Behav. 2018, 89, 182-190. [CrossRef]

16. Delello, J.A.; McWhorter, R.R.; Goette, W. College Students' Attraction to the Mobile Augmented Reality Game Pokémon Go. Int. J. Gaming Comput. Mediat. Simul. 2018, 10,1-19. [CrossRef]

17. Adlakha, D.; Marquet, O.; Hipp, J.A.; Tully, M.A. Pokémon GO or Pokémon Gone: How can cities respond to trends in technology linking people and space? Cit. Health 2017, 1, 1-6. [CrossRef]

18. Gibbs, S. Available online: https://www.theguardian.com/technology/2016/jul/25/pokemon-go-what-is-agym-how-to-win-battles (accessed on 17 July 2019).

19. McWhirter, A. Pokémon GO and No Man's Sky: Sandbox gaming's next level in tech-heavy society. Int. J. Jung. St. 2016, 9, 66-71. [CrossRef]

20. Jang, S.; Liu, Y. Continuance use intention with mobile augmented reality games: Overall and multigroup analyses on Pokémon Go. Inform. Technol. Peopl. 2019, in press. [CrossRef]

21. Zsila, A.; Orosz, G.; Bőthe, B.; Tóth-Király, I.; Király, O.; Griffiths, M.; Demetrovics, Z. An empirical study on the motivations underlying augmented reality games: The case of Pokémon Go during and after Pokémon fever. Pers. Indiv. Differ. 2018, 133, 56-66. [CrossRef]

22. Morschheuser, B.; Riar, M.; Hamari, J.; Maedche, A. How games induce cooperation? A study on the relationship between game features and we-intentions in an augmented reality game. Comput. Hum. Behav. 2017, 77, 169-183. [CrossRef]

23. Badrinarayanan, V.A.; Sierra, J.J.; Martin, K.M. A dual identification framework of online multiplayer video games: The case of massively multiplayer online role playing games (MMORPGs). J. Bus. Res. 2015, 68, 1045-1052. [CrossRef]

24. Rezaei, S.; Ghodsi, S.S. Does value matters in playing online game? An empirical study among massively multiplayer online role-playing games (MMORPGs). Comput. Hum. Behav. 2014, 35, 252-266. [CrossRef]

25. Muñoz-Saavedra, L.; Miró-Amarante, L.; Domínguez-Morales, M. Augmented and Virtual Reality Evolution and Future Tendency. Appl. Sci. 2020, 10, 322. [CrossRef]

26. Swanson, D.L. Gratification seeking, media exposure, and audience interpretations: Some direction for research. J. Broadcast. Electron. 1987, 31, 237-255. [CrossRef]

27. Blumler, J.G.; Katz, E. The Uses of Mass Communications: Current Perspectives on Gratifications Research; Sage: Berlin, Germany, 1974.

28. Krause, A.E.; North, A.C.; Heritage, B. The uses and gratifications of using Facebook music listening applications. Comput. Hum. Behav. 2014, 39, 71-77. [CrossRef]

29. Stafford, T.F.; Stafford, M.R.; Schkade, L.L. Determining uses and gratifications for the internet. Decision Sci. 2004, 35, 259-288. [CrossRef]

30. Herzog, H. Professor quiz: A gratification study. In Radio and the Printed Page; Lazarsfeld, P.F., Stanton, F.N., Eds.; Duell, Sloan \& Pearce: New York, NY, USA, 1940; pp. 64-93.

31. Lee, C.S.; Ma, L. News sharing in social media: The effect of gratifications and prior experience. Comput. Hum. Behav. 2012, 28, 331-339. [CrossRef]

32. Lin, Y.-H.; Hsu, C.-L.; Chen, M.-F.; Fang, C.-H. New gratifications for social word-of-mouth spread via mobile SNSs: Uses and gratifications approach with a perspective of media technology. Telemat. Informat. 2017, 34, 382-397. [CrossRef]

33. Lim, H.; Kumar, A. Variations in consumers' use of brand online social networking: A uses and gratifications approach. J. Ret. Cons. Serv. 2019, 51, 450-4457. [CrossRef] 
34. Ray, A.; Dhir, A.; Bala, P.K.; Kaur, P. Why do people use food delivery maps (FDA)? A uses and gratification theory perspective. J. Ret. Consum. Serv. 2019, 51, 221-230. [CrossRef]

35. Bracken, C.; Lombard, M. Uses and gratifications: A classic methodology revisited. N. Jer J. Comm. 2001, 9 , 103-116. [CrossRef]

36. Bantz, C.R. Exploring uses and gratifications: A comparison of reported uses of television and reported uses of favorite program type. Commun. Res. 1982, 9, 352-379. [CrossRef]

37. Leung, L.; Wei, R. The gratification of pager user: Sociability, information seeking, entertainment, utility, and fashion and status. Telemat. Informat. 1998, 15, 253-264. [CrossRef]

38. Flanagin, A.J.; Metzger, M.J. Internet use in the contemporary media environment. Hum. Commun. Res. 2001, 27, 153-181. [CrossRef]

39. Ferguson, D.A.; Perse, E.M. The World Wide Web as a functional alternative to television. J. Broadcast. Electron. 2000, 44, 155-174. [CrossRef]

40. Luo, M.M.; Remus, W. Uses and gratifications and acceptance of Web-based information services: An integrated model. Comput. Hum. Behav. 2014, 38, 281-295. [CrossRef]

41. Gallego, M.D.; Bueno, S.; Noyes, J. Second Life adoption in education: A motivational model based on Uses and Gratifications theory. Comput. Educ. 2016, 100, 81-93. [CrossRef]

42. Mäntymäki, M.; Riemer, K. Digital natives in social virtual worlds: A multi-method study of gratifications and social influences in Habbo Hotel. Int. J. Inform. Manag. 2014, 34, 210-220. [CrossRef]

43. Gan, C.; Li, H. Understanding the effects of gratifications on the continuance intention to use WeChat in China: A perspective on uses and gratifications. Comput. Hum. Behav. 2018, 78, 306-315. [CrossRef]

44. Phua, J.; Jin, S.V.; Kim, J. Uses and gratifications of social networking sites for bridging and bonding social capital: A comparison of Facebook, Twitter, Instagram, and Snapchat. Comput. Hum. Behav. 2017, 72, 115-122. [CrossRef]

45. Luo, M.M.; Chea, S.; Chen, J.-S. Web-based information service adoption: A comparison of the motivational model and the uses and gratifications theory. Decis. Support. Syst. 2011, 51, 21-30. [CrossRef]

46. Zhang, L.; Zhang, W. Real-time Internet news browsing: Information vs. experience-related gratifications and behaviors. Comput. Hum. Behav. 2013, 29, 2712-2721. [CrossRef]

47. Wu, J.-H.; Wang, S.-C.; Tsai, H.-H. Falling in love with online games: The uses and gratifications perspective. Comput. Hum. Behav. 2010, 26, 1862-1871. [CrossRef]

48. Miller, B. They're the modern-day gay bar: Exploring the uses and gratifications of social networks for men who have sex with men. Comput. Hum. Behav. 2015, 51, 476-482. [CrossRef]

49. Ku, Y.-C.; Chen, R.; Zhang, H. Why do users continue using social networking sites? An exploratory study of members in the United States and Taiwan. Inform. Manag. 2013, 50, 571-581. [CrossRef]

50. Palmgreen, P.C.; Wenner, L.A.; Rosengren, K.E. Uses and gratifications research: The past 10 years. In Uses and Gratifications Research: Current Perspectives; Rosengren, K.E., Wenner, L.A., Palmgreen, P.C., Eds.; Sage Publications: Beverly Hills, CA, USA, 1985; pp. 11-37.

51. Wurff, R. Are News Media Substitutes? Gratifications, Contents, and Uses. J. Media Econ. 2011, $24,139-157$. [CrossRef]

52. Zeng, L. More than Audio on the Go: Uses and Gratifications of MP3 Players. Commun. Res. Rep. 2011, 28, 97-108. [CrossRef]

53. Li, H.; Liu, Y.; Xu, X.; Heikkilä, J.; Heijden, H. Modeling hedonic is continuance through the uses and gratifications theory: An empirical study in online games. Comput. Hum. Behav. 2015, 48, 261-272. [CrossRef]

54. Venkatesh, V.; Brown, S.A. A longitudinal investigation of personal computers in Homes: Adoption determinants and emerging challenges. Mis. Quart. 2001, 25, 71-102. [CrossRef]

55. Hausman, A.V.; Siekpe, J.S. The effect of web interface features on consumer online purchase intentions. J. Bus. Res. 2009, 6, 5-13. [CrossRef]

56. Ghazali, E.; Mutum, D.S.; Woon, M.-Y. Exploring player behavior and motivations to continue playing Pokémon GO. Inform. Technol. Peopl. 2019, 32, 646-667. [CrossRef]

57. Huang, M.; Ali, R.; Liao, J. The effect of user experience in online games on word of mouth: A pleasure-arousal-dominance (PAD) model perspective. Comput. Hum. Behav. 2017, 75, 329-338. [CrossRef]

58. Liu, C.-C. Understanding player behavior in online games: The role of gender. Technol. Forecast. Soc. 2016, 111, 265-274. [CrossRef] 
59. Liu, I.L.B.; Cheung, C.M.K.; Lee, M.K.O. Understanding Twitter Usage: What Drive People Continue to Tweet. Pacis 2010, 92, 928-939.

60. Chen, C.; Leung, L. Are you addicted to Candy Crush Saga? An exploratory study linking psychological factors to mobile social game addiction. Telemat. Informat. 2016, 33, 1155-1166. [CrossRef]

61. Ha, Y.W.; Kim, J.; Libaque-Saenz, C.F.; Chang, Y.; Park, M.-C. Use and gratifications of mobile SNSs: Facebook and KakaoTalk in Korea. Telemat. Informat. 2015, 32, 425-438. [CrossRef]

62. Ryan, R.M.; Deci, E.L. Intrinsic and Extrinsic Motivations: Classic Definitions and New Directions. Contemp. Educ. Psychol. 2000, 25, 54-67. [CrossRef]

63. Lee, J.; Lee, M.; Choi, H. Social network games uncovered: Motivations and their attitudinal and behavioral outcomes. Cyb. Behav. Soc. Netw. 2012, 15, 643-648. [CrossRef]

64. Shiau, W.-L.; Luo, M.M. Factors affecting online group buying intention and satisfaction: A social exchange theory perspective. Comput. Hum. Behav. 2012, 28, 2431-2444. [CrossRef]

65. Baek, Y.M.; Cho, Y.; Kim, H. Attachment Style and its Influence on the Activities, Motives, and Consequences of SNS Use. J. Broadcast. Electron. 2014, 5, 522-541. [CrossRef]

66. Luo, X. Uses and Gratifications Theory and E-Consumer Behaviors. J. Inter. Advert. 2002, 2, 34-41. [CrossRef]

67. Vincent, R.C.; Basil, M.D. College students' news gratifications, media use, and current events knowledge. J. Broadcast. Electron. 1997, 41, 380-392. [CrossRef]

68. Kim, Y.; Ross, S. An exploration of motives in sport video gaming. Int. J. Sport. Market. Sponsor. 2006, 8, 28-40. [CrossRef]

69. Sherry, J.; Lucas, K.; Greenberg, B.S.; Lachlan, K. Video game uses and gratifications as predictors of use and game preference. In Motives, Responses, and Consequences Playing Video Games; Vorderer, P., Bryant, J., Eds.; Lawrence Erlbaum Associates: Mahwah, NJ, USA, 2006; pp. 213-224.

70. Scharkow, M.; Festl, R.; Vogelgesang, J.; Quandt, T. Beyond the core-gamer: Genre preferences and gratifications in computer games. Comput. Hum. Behav. 2015, 44, 293-298. [CrossRef]

71. Greenberg, B.S.; Sherry, J.; Lachlan, K.; Lucas, K.; Holmstrom, A. Orientations to video games among gender and age groups. Simulat. Gaming 2010, 41, 238-259. [CrossRef]

72. Camarero, C.; Garrido, M.-J.; San Jose, R. What Works in Facebook Content Versus Relational Communication: A Study of their Effectiveness in the Context of Museums. Int. J. Hum. Comput. Int. 2018, 34, 1119-1134. [CrossRef]

73. Gan, C. Understanding WeChat users' liking behavior: An empirical study in China. Comput. Hum. Behav. 2017, 68, 30-39. [CrossRef]

74. Grant, I.; O'Donohoe, S. Why young consumers are not open to mobile marketing communications. Int. J. Advert. 2007, 26, 223-246. [CrossRef]

75. Sjöblom, M.; Törhönen, M.; Hamari, J.; Macey, J. Content structure is king: An empirical study on gratifications, game genres and content type on Twitch. Comput. Hum. Behav. 2017, 73, 161-171. [CrossRef]

76. De Grove, F.; Cauberghe, V.; Van Looy, J. In Pursuit of Play: Toward a Social Cognitive Understanding of Determinants of Digital Play. Communication Theory Commun. Theor. 2014, 24, 205-223. [CrossRef]

77. Courtois, C.; Mechant, P.; De Marez, L.; Verleye, G. Gratifications and Seeding Behavior of Online Adolescents. J. Comput. Mediat. Comm. 2009, 1, 109-137. [CrossRef]

78. Lev-On, A. Uses and gratifications of members of communities of practice. Online Inform. Rev. 2015, 39, 163-178. [CrossRef]

79. Chang, I.C.; Liu, C.C.; Chen, K.C. The effects of hedonic/utilitarian expectations and social influence on continuance intention to play online games. Internet Res. 2014, 24, 21-45. [CrossRef]

80. Wei, P.S.; Lu, H.P. Why do people play mobile social games? An examination of network externalities and of uses and gratifications. Internet Res. 2014, 24, 313-331. [CrossRef]

81. Engl, S.; Nacke, L.E. Contextual influences on mobile player experience-a game user experience model. Entert. Comput. 2013, 4, 83-91. [CrossRef]

82. Zhou, S.X.; Leung, L. Gratifications, loneliness, leisure boredom, and self-esteem as predictors of SNS-game addiction and usage pattern among Chinese college students. Int. J. Cyber Behav. Psych. Learn. 2012, 2, $34-48$. [CrossRef]

83. Kim, M.G.; Kim, J. Cross-validation of reliability, convergent and discriminant validity for the problematic online game use scale. Comput. Hum. Behav. 2010, 26, 389-398. [CrossRef] 
84. Dolan, R.; Conduit, J.; Fahy, J.; Goodman, S. Social media engagement behaviour: A uses and gratifications perspective. J. Strateg. Mark. 2016, 24, 261-277. [CrossRef]

85. Rui, J.R.; Stefanone, M.A. The Desire for Fame: An Extension of Uses and Gratifications Theory. Comm. Stud. 2016, 67, 399-418. [CrossRef]

86. Whiting, A.; Williams, D. Why people use social media: A uses and gratifications approach. Qual. Mark. Res. 2013, 16, 362-369. [CrossRef]

87. Gao, Q.; Feng, C. Branding with social media: User gratifications, usage patterns, and brand message content strategies. Comput. Hum. Behav. 2016, 63, 868-890. [CrossRef]

88. Merhi, M.I. Towards a framework for online game adoption. Comput. Hum. Behav. 2016, 60, $253-263$. [CrossRef]

89. van Reijmersdal, E.A.; Jansz, J.; Peters, O.; van Noort, G. Why girls go pink: Game character identification and game-players' motivations. Comput. Hum. Behav. 2013, 29, 2640-2649. [CrossRef]

90. Krämer, N.C.; Winter, S.; Benninghoff, B.; Gallus, C. How "social" is Social TV? The influence of social motives and expected outcomes on the usage of Social TV applications. Comput. Hum. Behav. 2015, 51, 255-262. [CrossRef]

91. Suznjevic, M.; Matijasevic, S. Why MMORPG players do what they do: Relating motivations to action categories. Int. J. Adv. Media Comm. 2010, 4, 405-424. [CrossRef]

92. Choi, D.; Kim, J. Why people continue to play online games: In search of critical design factors to increase customer loyalty to online contents. Cyberpsychol. Behav. 2004, 7, 11-24. [CrossRef]

93. Chen, B.; Marcus, J. Students' self-presentation on Facebook: An examination of personality and self-construal factors. Comput. Hum. Behav. 2012, 28, 2091-2099. [CrossRef]

94. Tifferet, S.; Vilnai-Yavetz, I. Self-presentation in LinkedIn portraits: Common features, gender, and occupational differences. Comput. Hum. Behav. 2018, 80, 33-48. [CrossRef]

95. Park, S.; Chung, N. Mediating roles of self-presentation desire in online game community commitment and trust behavior of Massive Multiplayer Online Role-Playing Games. Comput. Hum. Behav. 2011, 27, 2372-2379. [CrossRef]

96. Vasalou, A.; Joinson, A.N. Me, myself and I: The role of interactional context on self-presentation through avatars. Comput. Hum. Behav. 2009, 25, 510-520. [CrossRef]

97. Nunally, J.C.; Bernstein, I.H. Psychometric Theory, 3rd ed.; McGraw-Hill Inc.: New York, NY, USA, 1994.

98. Fornell, C.; Larcker, D.F. Evaluating structural equation models with unobservable variables and measurement error. J. Mark. Res. 1981, 18, 39-50. [CrossRef]

99. Hair, J.F.; Anderson, R.E.; Tatham, R.L.; Black, W.C. Multivariate Data Analysis, 5th ed.; Prentice Hall: Upper Saddle River, NJ, USA, 2005.

100. Segars, A.H. Assessing the unidimensionality of measurement a paradigm and illustration within the context of information systems research. Omega 1997, 25, 107-121. [CrossRef]

101. Son, H.; Park, Y.; Kim, C.; Chou, J.-S. Toward an understanding of construction professionals' acceptance of mobile computing devices in South Korea: An extension of the technology acceptance model. Automat. Constr. 2012, 28, 82-90. [CrossRef]

(C) 2020 by the authors. Licensee MDPI, Basel, Switzerland. This article is an open access article distributed under the terms and conditions of the Creative Commons Attribution (CC BY) license (http://creativecommons.org/licenses/by/4.0/). 